\title{
L'usine marémotrice de la Rance
}

The Rance tidal power plant

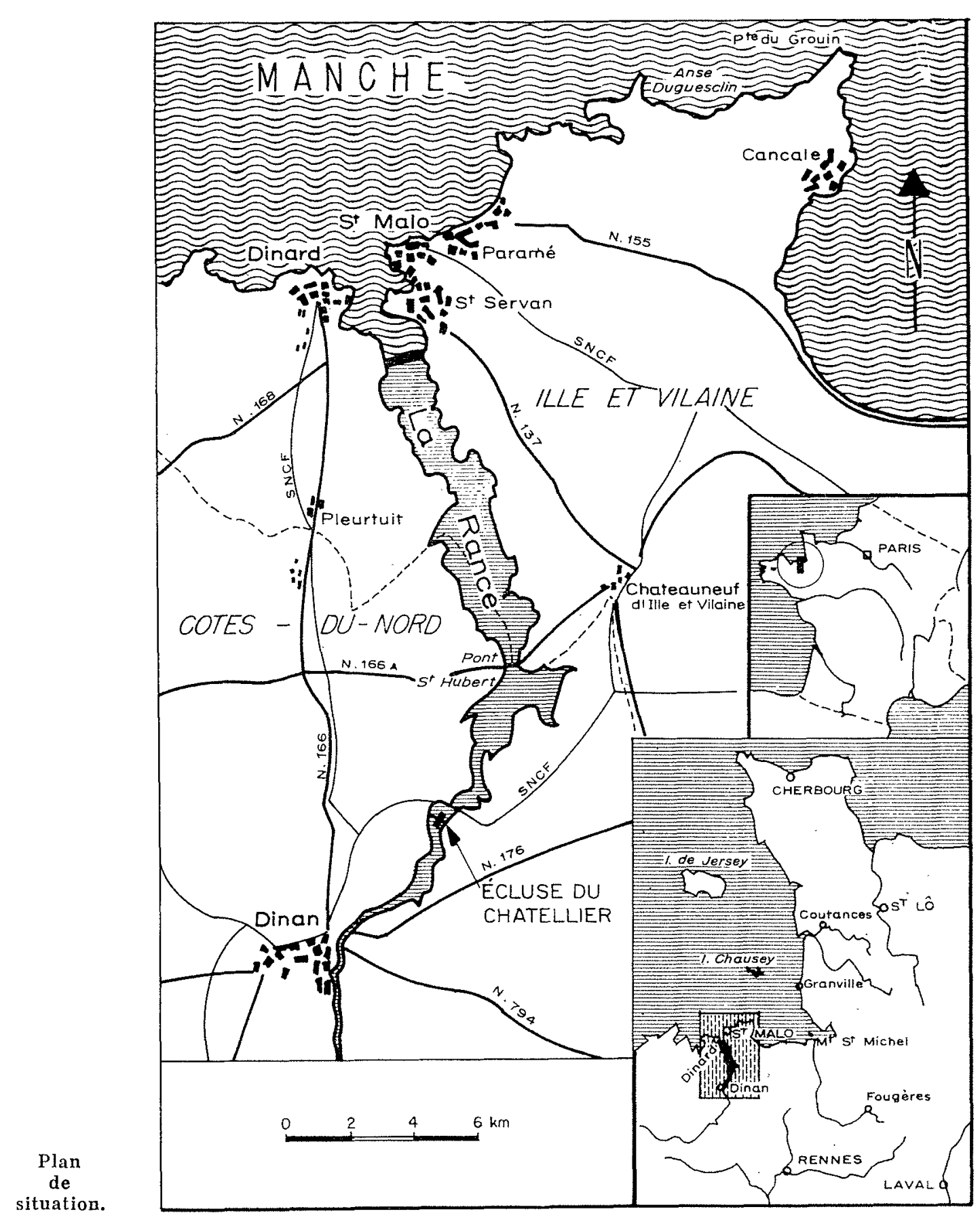




\section{LES MARÉES LOCALES}

\section{Amplitudes}

Les côtes françaises bretonnes de la Manche sont une des régions du Globe où les marées sont les plus fortes. Ceci s'explique en particulier par l'obstacle apporté par la presqu'île du Cotentin à l'onde de marée venant de l'Atlantique.

Dans l'estuaire de la Rance, la différence de niveau entre une pleine mer (marée haute) et une hasse mer (marée basse) consécutives peut atteindre $13,50 \mathrm{~m}$.

Les marées sont du type semi-diurne. Il y a deux pleines mer et deux basses mers en $24 \mathrm{~h} .50 \mathrm{mn}$.

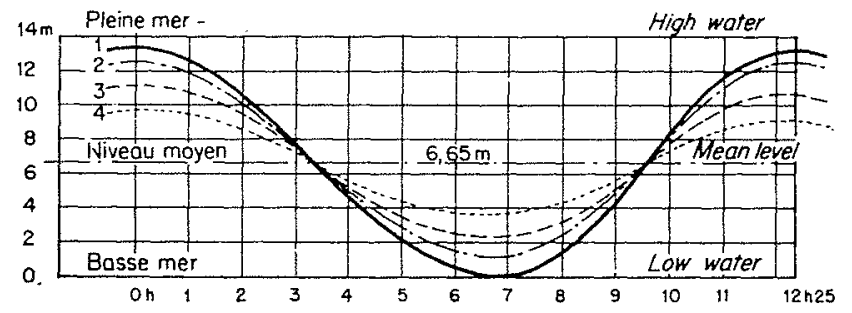

\section{LOCAL TIDES}

\section{Ranges}

The Brittany coast on the English Channel is one of the regions in the world where the tides are the strongest. This is doubtless due in part to the barrier formed by the Cotentin peninsula to the tide wave sweeping in from the Atlantic.

In the Rance estuary the difference between the level of consecutive high and low water may be as much as $13,5 \mathrm{~m}$.

The tides are of the semi-diurnal type. There are two high water and two low water in 24 hours 50 minutes.

\section{Amplitudes}

1. Marée exceptionnelle de vive eau d'équinoxe.

2. Marée de vive eau moyenue.

3. Marée moyenne.

4. Marée de morte eau moyenne.

\section{Ranges}

1. Exceptional equinoctial spring tide.

2. Medium, spring tide.

3. Medium tide.

4. Medium neap tide.

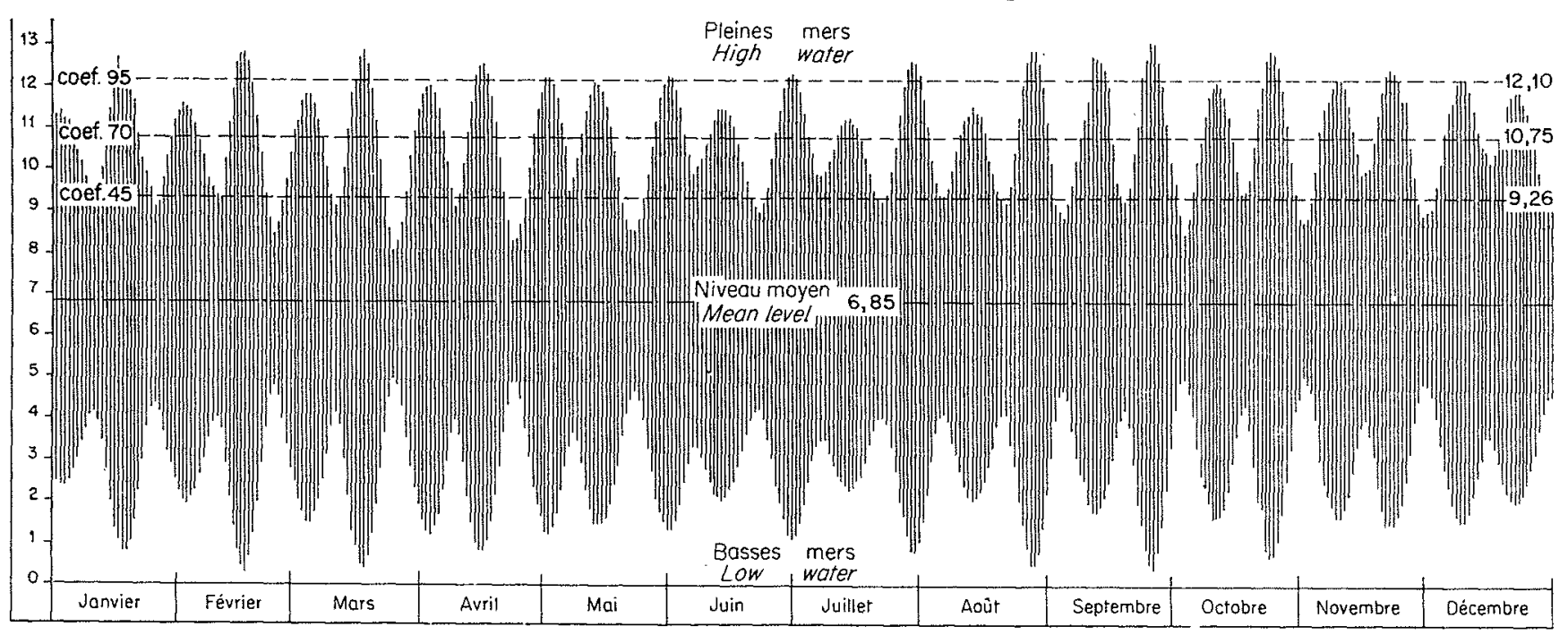

Marées de l'année 1961.

Tides during the year 1961.

En marée de vive eau d'équinoxe, le débit maximal qui passe dans la Rance atteint tant au flot qu'au jusant, $18000 \mathrm{~m}^{3} / \mathrm{s}$, soit trois fois environ le débit du Rhône en crue à Avignon.

\section{L'UTILISATION DE L'ÉNERGIE DES MARÉES}

Cette utilisation dans l'usine la plus simple, conduit à réaliser des remplissages et des vidages successifs d'un bassin (estuaire) avec des turbines et des vannes.
During the equinoctial spring tide the maximum flow in the Rance during flow or ebb reaches $18000 \mathrm{~m}^{3} / \mathrm{sec}$, or about three times the flow of the Rhône in flood at Avignon.

\section{THE USE OF TIDAL ENERGY}

In the most simple power station the method is to fill and empty the basin (estuary) successively, by means of turbines and sluices. 


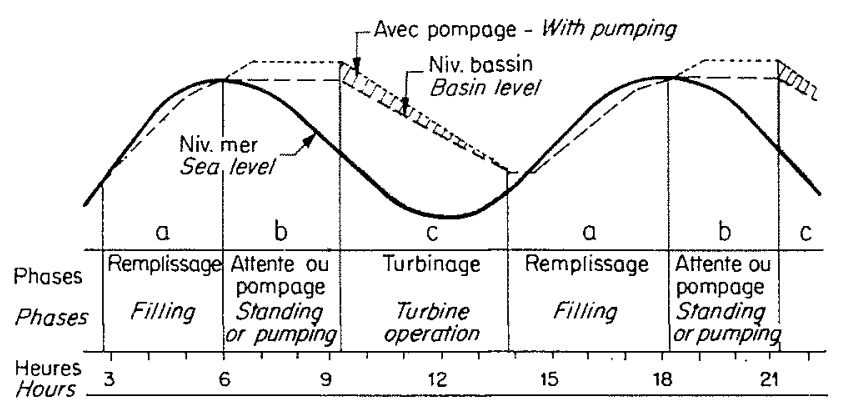

Simple effet au vidage.

Single-way operation on emptying.

\section{Simple effet au vidage}

A marée montante, on remplit le bassin par les vannes. A la pleine mer, on ferme les vannes et on attend, pour vider le bassin par les turbines, que la mer en se retirant ait créé une hauteur de chute suffisante.

C'est l'exploitation la plus simple, qui était réalisée autrefois dans les moulins à marée.

Ce cycle peut être amélioré en utilisant l'énergie disponible sur le réseau aux heures creuses pour pomper l'eau de la mer afin de surélever le niveau du bassin et d'augmenter le volume turbinable.

\section{Simple effet au remplissage}

Dans ce cas, l'énergie est produite par remplissage du bassin en turbinant à marée montante de la mer vers le bassin.

\section{Double effet}

C'est la combinaison des deux cycles précédents. L'énergie est produite à la fois lors du remplissage et lors du vidage du bassin.

\section{Sesqui effet}

Ce cycle consiste à utiliser deux marées successives de «vive eau » pour réaliser trois turbinages (d'où le nom de sesqui effet ou effet $3 / 2$ ), avec deux pompages intermédiaires permettant d'améliorer les turbinages postérieurs.

Parmi les nombreux cycles que l'exploitant aura à sa disposition, le choix devra se porter sur celui qui convient le mieux, selon l'ampli-

\section{Single-way operation on emptying}

On the rising tide the basin is filled by opening the sluices. When the tide is at full the sluices are closed and the basin is not emptied by the turbines until the ebb has created an adequate head.

This is the simplest form of using tidal energy which was formely used in tidal mill wheels.

This cycle can be improved by using the energy available on the network during slack hours to pump the sea water into the basin to raise the level and increase the volume of water available for the turbines.

\section{Single-way operation on filling}

In this case, the energy is produced by passing the water through the turbines on the rising tide, from the sea towards the basin, thus filling the latter.

\section{Double-way operation}

This is the combination of the two preceding cycles. The energy is produced during both filling and emptying of the basin.

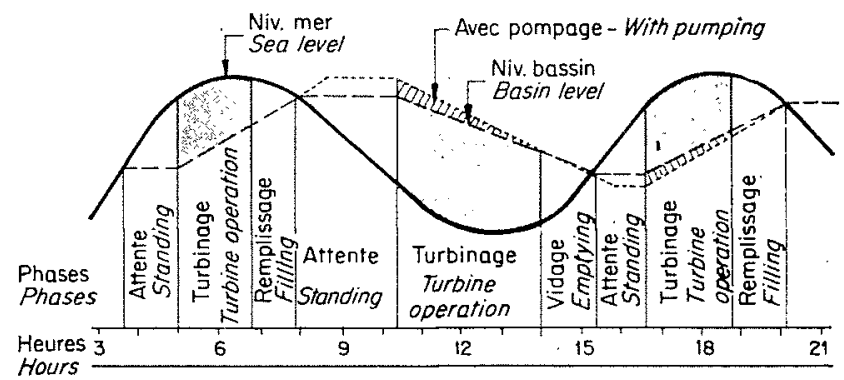

Double effet.

Double way operation.

\section{Sesqui operation}

This cycle consists making use of two successive spring tides to pass the water three times through the turbines (whence the name \&sesqui operation » or $3 / 2$ operation), with two intermediate pumpings which improve the volume of water subsequently available to the turbines.

Among the numerous cycles available to the operator, he will select the one which is best

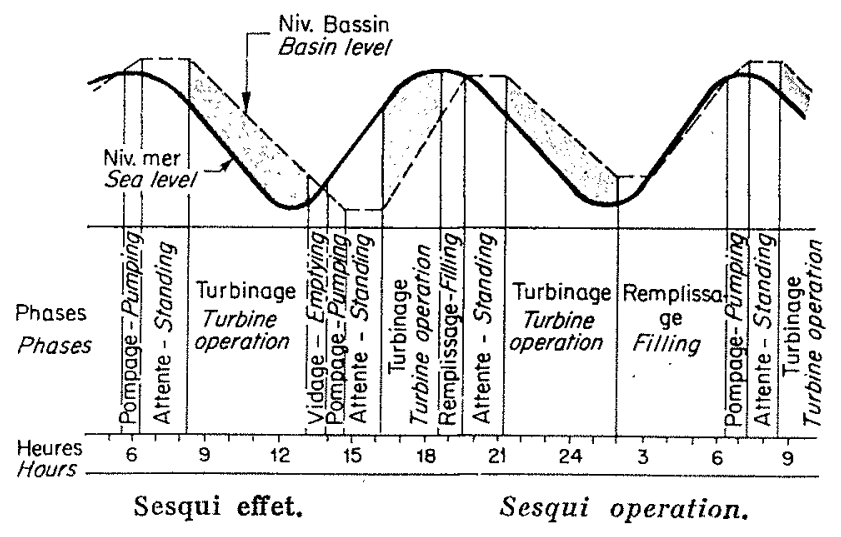


tude de la marée et la valeur de l'énergie aux diverses heures de la journée. Pour un prix constant de l'énergie, la recherche du meilleur cycle donnerait :

- Pour les faibles marées : simple effet répété avec pompage;

- Pour les marées moyennes : double effet répété avec pompage;

- Pour les fortes marées : sesqui effet avec pompage;

- Pour les marées exceptionnelles : double effet sans pompage.

Grâce au fonctionnement à double effet et au pompage, on peut donc obtenir une exploitation «sur mesure», fonction de l'heure et de l'amplitude de la marée. De cette façon, on tend à abandonner le rythme lunaire des marées pour se rapprocher du rythme solaire qui est celui des activités humaines.

\section{SITE DE L'AMÉNAGEMENT}

L'usine marémotrice de la Rance est implantée entre la pointe de la Briantais, rive droite, et la pointe de la Brebis, rive gauche; la largeur de la Rance à cet endroit est de $750 \mathrm{~m}$ environ. adapted to the tidal range and the amount of energy at various times of the day. To ensure a constant cost of energy, the most favourable cycle would be:

- for small tides: repeated single-way operation with pumping;

- for medium tides: repeated double-way operation with pumping;

- for strong tides: sesqui operation with pumping;

- for exceptional tides: double-way operation without pumping.

It follows that by using double-way operation and pumping a «made to measure» operation can be ensured according to the hours and the tidal range. In this way, the endency is to abandon the lunar tide rhythm to approach the solar rhythm which is that governing human activity.

\section{SITE OF DEVELOPMENT}

The tidal power station is sited between the Briantais Point, right bank and the Brebis point, left bank where the Rance is about $750 \mathrm{~m}$ wide.

The lay-out straddles the Chalibert rock.

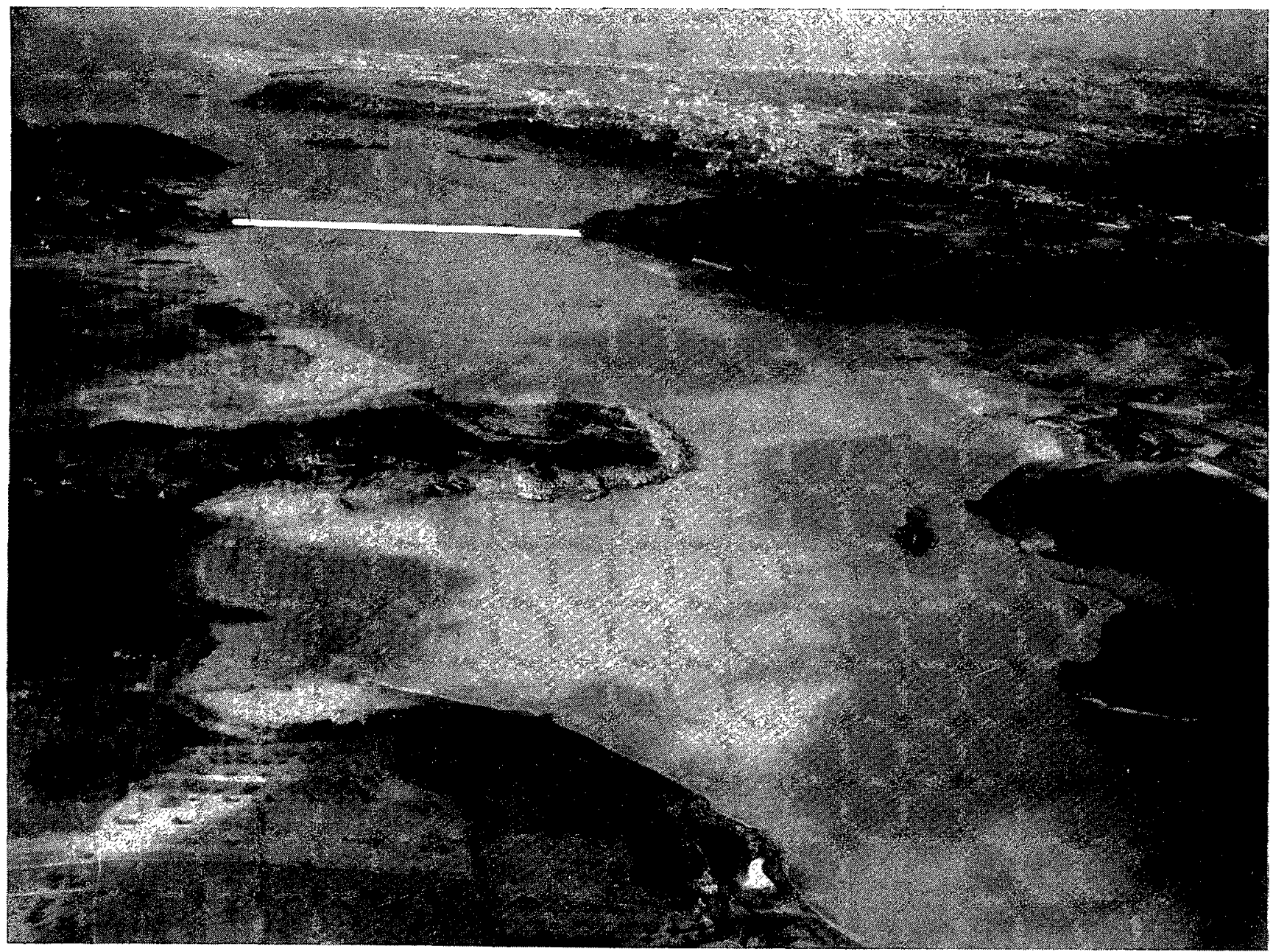


Le tracé passe par l'îlot de Chalibert.

Les sondages ont montré que le lit était constitué par une roche granitique, recouverte par endroits de sable et de galets.

Les fonds les plus profonds sont à 12 mètres au-dessous du zéro des cartes marines.

La retenue s'étend jusqu'à l'écluse du Chatellier, près de Dinan, sur une vingtaine de kilomètres.

Superficie du bassin (à $+13,50$ C.M.) $22 \mathrm{~km}^{2}$ Volume utile du bassin..... $184000000 \mathrm{de} \mathrm{m}^{3}$ (entre 0,00 et $+13,50$ C.M.)
Soundings have shown that the river bed consists of granitic rock covered in places by sand and pebbles.

The greatest depth is $12 \mathrm{~m}$ below the zero of the sea charts.

The storage reservoir extends as far as Le Chatellier lock near Dinan, over some $20 \mathrm{~km}$.

Area of basin (at $+13,5$ S.C.) :

$22 \mathrm{~km}^{2}$

Useful volume of basin: 184 millions cubic metres. (between $+0,00$ and $+13,50 \mathrm{~S}$ C.)

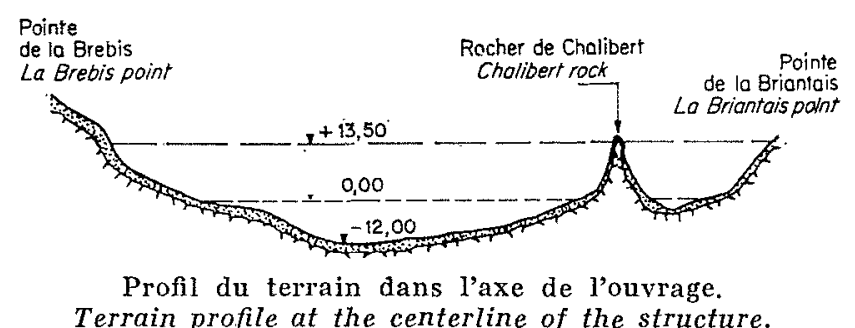

\section{DESCRIPTION SOMMAIRE DES OUVRAGES}

En partant de la rive gauche, les ouvrages comprennent :

\section{L'écluse.}

Implantée dans la pointe de la Brebis. Longueur du sas $65 \mathrm{~m}$; largeur $13 \mathrm{~m}$. Radier à la cote +2.00 C.M.

\section{L'usine.}

Située dans la partie profonde de la Rance.

C'est une digue creuse en béton dont les parements amont et aval sont raidis par des contreforts espacés de $13,30 \mathrm{~m}$. Le toit constitué par une voûte donne naissance à des poussées en sens inverse de celles de l'eau. Longueur totale $390 \mathrm{~m}$ environ. Largeur totale $53 \mathrm{~m}$. Partie supérieure arasée à la cote +15.00 C.M. Fondations à la cote $-10.00 \mathrm{C} . \mathrm{M}$. environ.

A l'intérieur sont installés :

- 24 groupes bulbe de $10 \mathrm{MW}$;

- 3 transformateurs de 80 MVA (à $225 \mathrm{kV}$ );

- 4 ponts roulants de $90 \mathrm{t}$.

Un ensemble de deux fois quatre groupes débite sur chaque transformateur, situé dans une travée de groupe spécialement agrandie côté mer.

Des câbles à huile à $225 \mathrm{kV}$ relient les transformateurs à un poste de départ situé sur la rive gauche.

L'accès à l'usine se fait par un puits implanté sur la plate-forme R.G. et une galerie passant sous l'écluse.

\section{BRIEF DESCRIPTION OF THE STRUCTURES}

Starting from the left bank, the structures comprises:

\section{The lock.}

Implanted the Brebis Point. Length of lockchamber $65 \mathrm{~m}$, width $13 \mathrm{~m}$. Apron at level $+2,00$ S.C.

\section{The power station.}

Situated in the deep part of the Rance. It consists of a hollow concrete dike, the up-stream and downstream faces of which are reinforced by buttresses $13,30 \mathrm{~m}$ apart. The roof formed by an arch sets up thrusts in the opposite direction to that of the flow. Length approximately $390 \mathrm{~m}$, total width $: 53 \mathrm{~m}$. Crest level + 15.00 S.C. foundations at about -10.00 S.C.

Inside are installed

-24 bulb set of $10 \mathrm{MW}$;

- 3 transformers of $80 \mathrm{MVA}(225 \mathrm{kV})$;

- 4 travelling cranes of $90 \mathrm{t}$.

Each transformer, situated in a bay especially enlarged on the side towards the sea, is fed by a battery of $2 \times 4$ sets.

$225 \mathrm{kV}$ oil-insulated cables connect the transformers to an outgoing station situated on the left bank.

Access to the power station is by a shaft situated on the left bank and a gallery passing under the lock. 

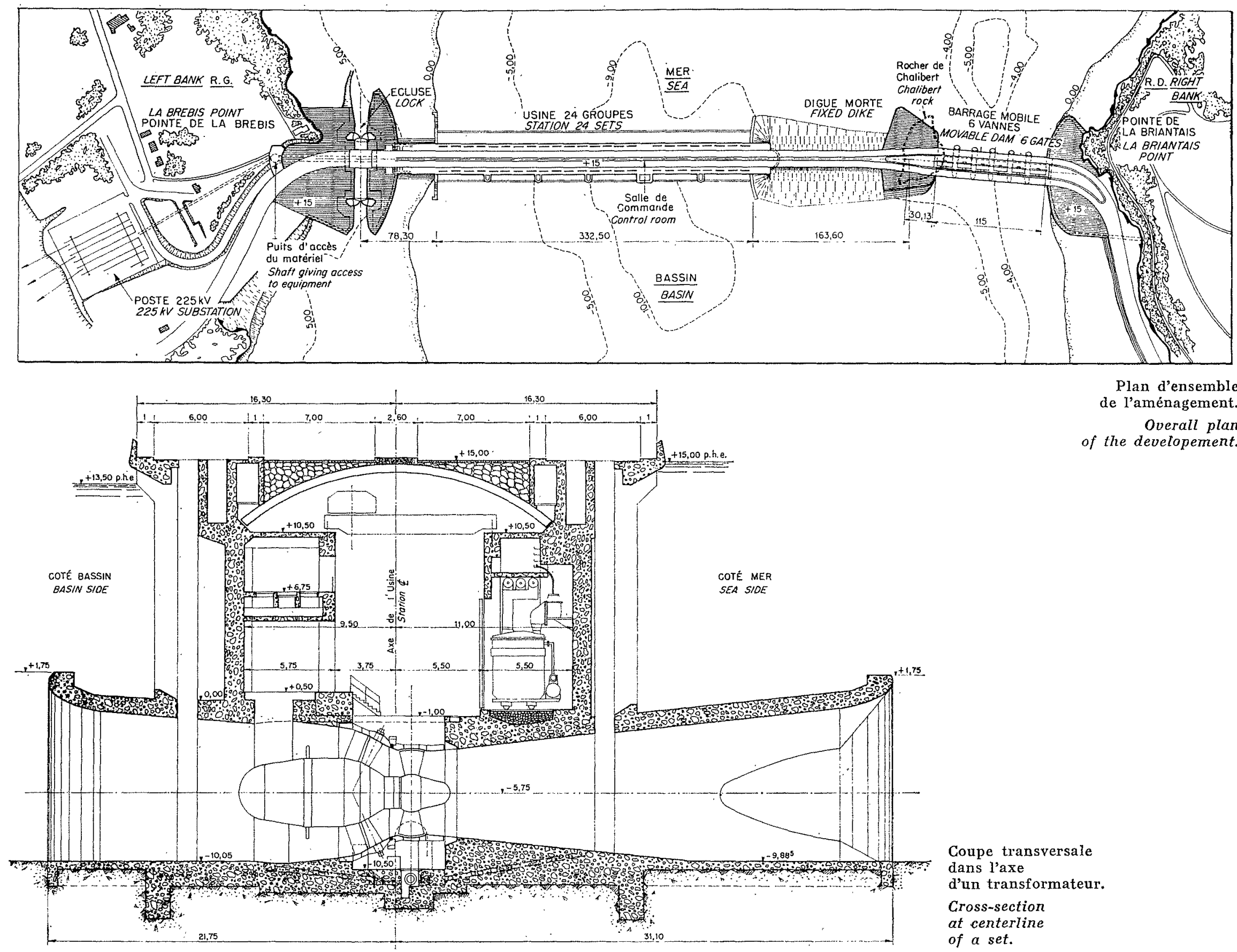

Coupe transversale

dans l'axe

d'un transto

Plan d'ensemble de l'aménagement. Overall plan of the developement. 


\section{La digue morte.}

Reliant l'extrémité Est de l'usine à l'îlot de Chalibert. Longueur $175 \mathrm{~m}$ environ.

\section{Le barrage mobile.}

Situé entre l'îlot de Chalibert et la R.D. Longueur $115 \mathrm{~m}$. Radier à la cote -4.00 C.M. 6 vannes wagon, largeur $15 \mathrm{~m}$, hauteur $10 \mathrm{~m}$.

L'ensemble de ces ouvrages est arasé à la cote + 15.00 C.M. et permettra ultérieurement l'établissement d'une route à grande circulation facilitant le trafic entre les deux rives de la Rance.

\section{LE GROUPE BULBE}

Il est composé d'une coque métallique en forme d'ogive contenant l'alternateur et d'une turbine Kaplan.

L'ensemble est placé dans un conduit horizontal.

Les avant-directrices servent de support.

Une cheminée débouchant dans la salle des machines permet d'accéder dans la coque.

Le groupe fonctionne soit en turbine, soit en pompe et dans les deux sens d'écoulement du flux.

\section{Caractéristiques}

TURBINE :

- Roue Kaplan à pales et directrices orientables;

- Nombre de pales : 4;

- Diamètre de la roue : $5,35 \mathrm{~m}$;

- Puissance : $10 \mathrm{MW}$;

- Vitesse : $94 \mathrm{tr} / \mathrm{mn}$;

- Vitesse d'emballement : $380 \mathrm{tr} / \mathrm{mn}$.

Alternateur :

- Accouplé directement à la turbine;

-- Tournant dans une atmosphère d'air à la pression de $2 \mathrm{~kg} / \mathrm{cm}^{2}$ absolus;

- Puissance : $10 \mathrm{MW}$ à $\operatorname{Cos} \varphi=1$.

\section{The fixed dike.}

Connecting the eastern end of the power station with the Chalibert rock. Length approx. $175 \mathrm{~m}$

\section{The movable dam.}

Situated between the Chalibert rock and the right bank. Length $115 \mathrm{~m}$. Apron level - 4.00 S.C. 6 fixed roller gates, width $15 \mathrm{~m}$, height $10 \mathrm{~m}$.

All of these structures are levelled out at +15 S.C. and will enable a main highway to be laid subsequently, thus facilitating traffic between the two banks of the Rance.

\section{THE BULB SET}

It is composed of a metal ogee shell containing the A. C. generator and a Kaplan turbine.

The assembly is placed in a horizontal duct.

The fixed guide vanes serve as support.

A shaft leading to the machine room gives access to the shell.

The set operates either as a turbine or as a pump and in both directions of flux.

\section{Characteristics}

TURBINE :

Kaplan wheel with adjustable runner blades and guide vanes:

- Number of runner blades: 4;

- Diameter of wheel : $5,35 \mathrm{~m}$;

- Capacity: 10 MW;

- Speed: 94 r.p.m.;

- Runaway speed: 380 r.p.m.

A.C. Generator :

- Directly coupled to the turbine;

- Rotating in air at an absolute pressure of $2 \mathrm{~kg} / \mathrm{cm}^{2}$;

- Capacity: $10 \mathrm{MW}$ at $\operatorname{Cos} \varphi=1$.

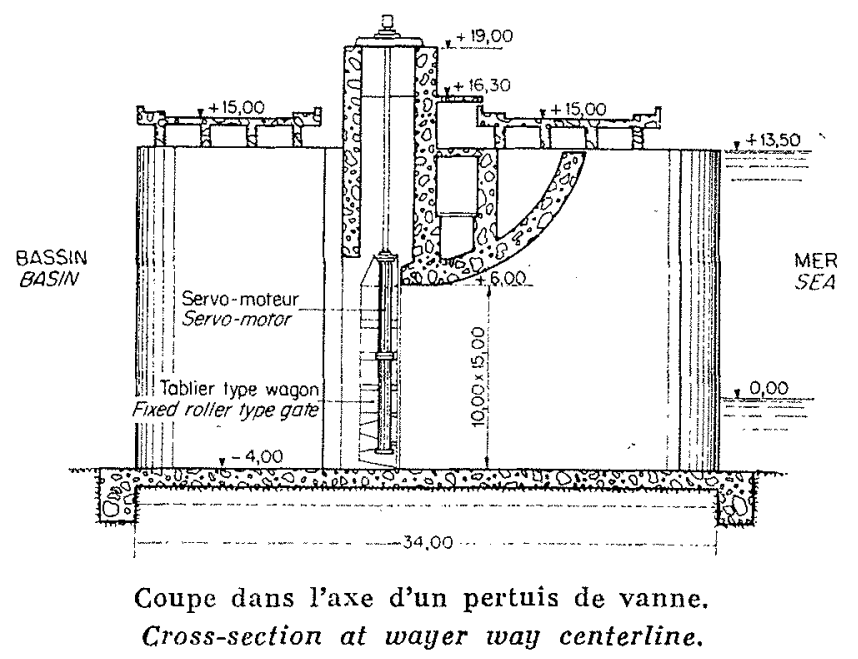




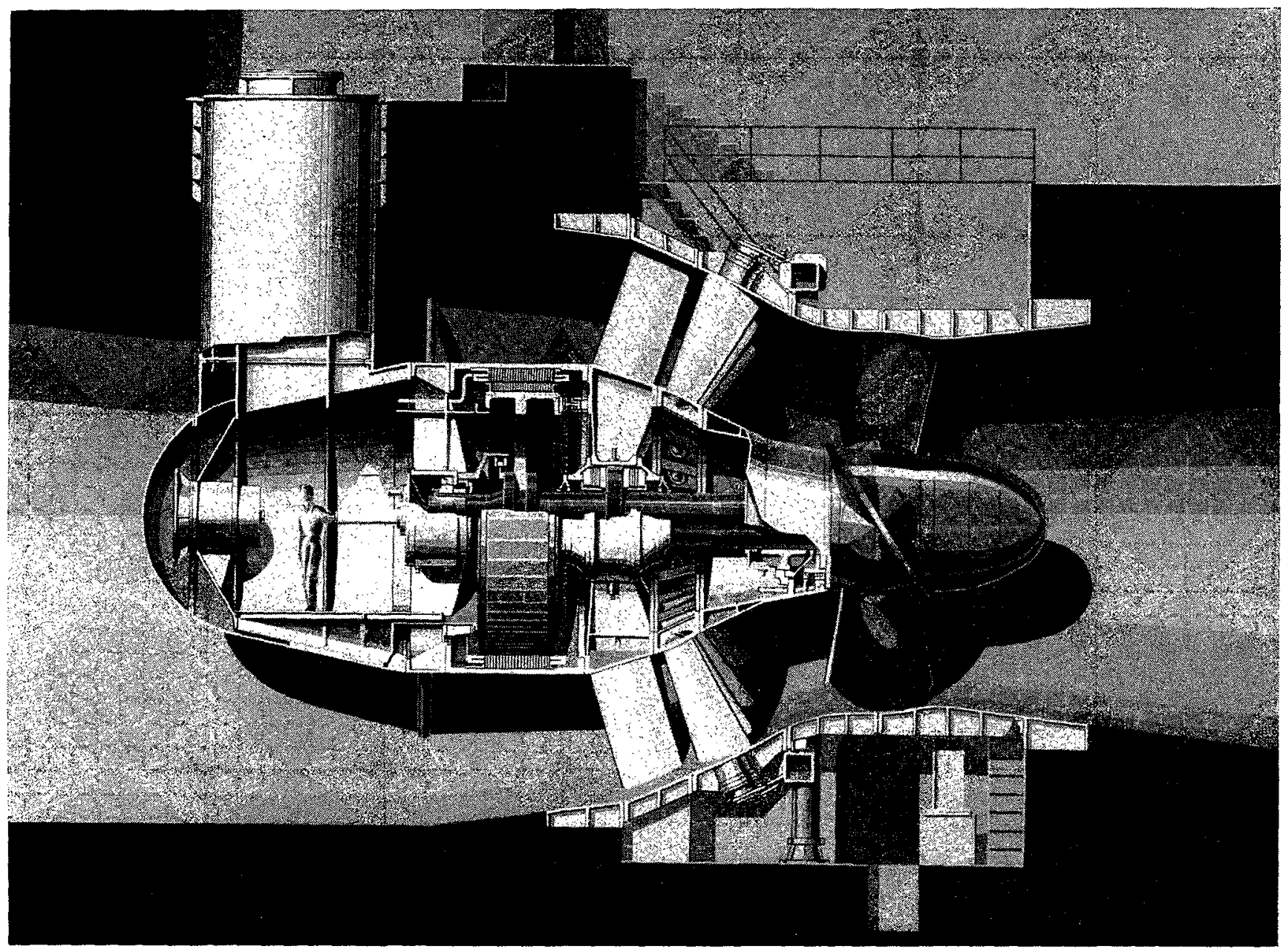

Groupe bulbe Rance.

Rance Bulb set.

\begin{tabular}{|c|c|c|c|c|c|}
\hline \multirow{2}{*}{ FONCTIONNEMENT EN TURBINE } & \multicolumn{5}{|c|}{ SOUS UNE CHUTE DE : } \\
\hline & $11 \mathrm{~m}$ & $9 \mathrm{~m}$ & $7 \mathrm{~m}$ & $5 \mathrm{~m}$ & $3 \mathrm{~m}$ \\
\hline 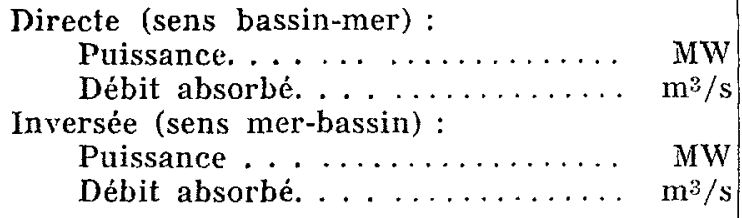 & $\begin{array}{r}10 \\
110 \\
10 \\
130\end{array}$ & $\begin{array}{r}10 \\
130 \\
10 \\
155\end{array}$ & $\begin{array}{l}10 \\
175 \\
9,5 \\
230\end{array}$ & $\begin{array}{r}8 \\
260 \\
5,5 \\
195\end{array}$ & $\begin{array}{r}3,2 \\
200 \\
2 \\
135\end{array}$ \\
\hline \multirow{2}{*}{ FONCTIONNEMENT EN POMPE } & \multicolumn{5}{|c|}{ SOUS UNE CHUTE DE : } \\
\hline & \multicolumn{2}{|l|}{$1 \mathrm{~m}$} & $2 \mathrm{~m}$ & \multicolumn{2}{|r|}{$3 \mathrm{~m}$} \\
\hline $\begin{array}{l}\text { Directe (sens bassin-mer) : } \\
\quad \text { Débit maximal pompé.......... } \mathrm{m}^{3} / \mathrm{s}\end{array}$ & \multicolumn{2}{|l|}{225} & 195 & & 170 \\
\hline
\end{tabular}




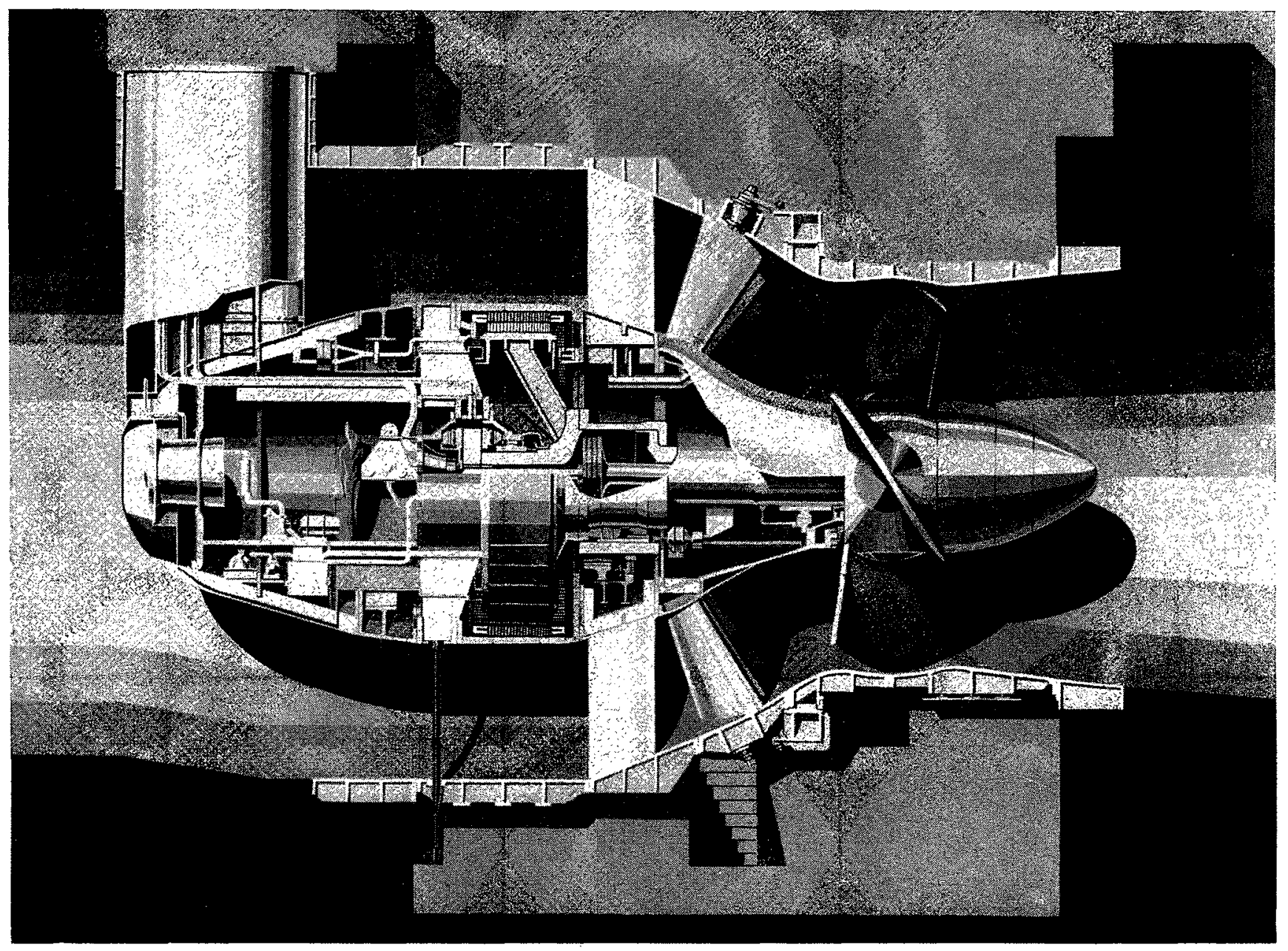

Groupe bulbe Saint-Malo.

Saint-Malo Bulb set.

Operation as a turbine

UNDER A HEAD OF:

\begin{tabular}{|c|c|c|c|c|c|}
\hline \multirow{2}{*}{ Operation as a tURBINE } & \multirow[b]{2}{*}{$11 \mathrm{~m}$} & \multirow[b]{2}{*}{$9 \mathrm{~m}$} & \multirow[b]{2}{*}{$7 \mathrm{~m}$} & \multirow[b]{2}{*}{$5 \mathrm{~m}$} & \multirow[b]{2}{*}{$3 \mathrm{~m}$} \\
\hline & & & & & \\
\hline 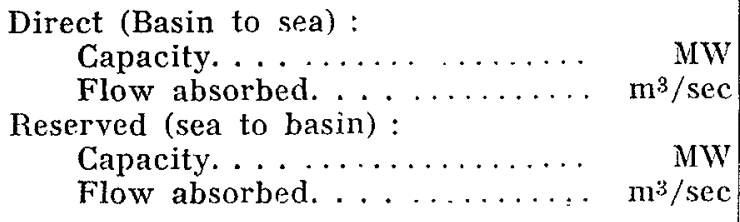 & $\begin{array}{r}10 \\
110 \\
10 \\
130\end{array}$ & $\begin{array}{r}10 \\
130 \\
10 \\
155\end{array}$ & $\begin{array}{l}10 \\
175 \\
9,5 \\
230\end{array}$ & $\begin{array}{c}8 \\
260 \\
\\
5,5 \\
195\end{array}$ & $\begin{array}{l}3,2 \\
200 \\
2 \\
135\end{array}$ \\
\hline \multirow{2}{*}{ OPERATION ON DIRECT PUMPING } & \multicolumn{5}{|c|}{ UNDER A HEAD OF: } \\
\hline & \multicolumn{2}{|l|}{$1 \mathrm{~m}$} & $2 \mathrm{~m}$ & \multicolumn{2}{|r|}{$3 \mathrm{~m}$} \\
\hline $\begin{array}{l}\text { Direct (Basin to sea): } \\
\quad \text { Maximum pump output....... } \mathrm{m}^{3} / \mathrm{sec}\end{array}$ & \multicolumn{2}{|c|}{225} & 195 & \multicolumn{2}{|r|}{170} \\
\hline
\end{tabular}


La conception du groupe Rance résulte des renseignements fournis par des groupes bulbes axiaux installés en rivière à :

- Cambeyrac sur la Truyère

(2 groupes de $5 \mathrm{MW}$ );

- Argentat sur la Dordogne

(1 groupe de 14 MW);

- Beaumont-Monteux sur l'Isère

(1 groupe de 8,5 MW);

et plus récemment à Saint-Malo, où un véritable groupe marémoteur a été installé dans une écluse désaffectée du port. Ses caractéristiques sont très voisines de celles des groupes qui seront utilisés à la Rance. (Groupe Saint-Malo : $9 \mathrm{MW}-88 \mathrm{tr} / \mathrm{mn}$ - diamètre roue : $5,80 \mathrm{~m}$.)

\section{MODE D'EXECUTION DES TRAVAUX}

Les ouvrages définitifs seront construits à sec, à l'intérieur de trois enceintes de batardeaux.

\section{Première phase}

Seront exécutées :

- Une enceinte rive gauche pour permettre la construction de l'ècluse;

Enceinte constituée de murs en béton exécutés à la marée et qui seront incorporés dans l'ouvrage définitif; cote d'arase + 14.00 C.M.

- Une enceinte rive droite s'appuyant sur l'îlot de Chalibert pour permettre la construction du barrage mobile.

Enceinte constituée par des gabions de palplanches à âme plate, remplis de sable.

Diamètre des gabions 16 à $19 \mathrm{~m}$. Cote d'arase +14.00 C.M.
The design of the Rance set is the result of data gathered from axial bulb sets installed in the rivers:

- Truyère at Cambeyrac (two $5 \mathrm{MW}$ sets),

- Dordogne at Argentat (one 14 MW set),

- Isère at Beaumont-Monteux (one 8,5 MW set);

and more recently at Saint-Malo where a veritable tidal power generating set has bee installed in a dis-used lock of the port. Its characteristic features approximate very closely those of the group which will be operated in the Rance. (Saint-Malo set: $9 \mathrm{MW}-88$ r.p.m. - wheel diameter: $5,80 \mathrm{~m}$.).

\section{ENGINEERING WORK}

The final structures will be erected under dry conditions, inside three enclosures formed by coffer-dams.

\section{1 st stage}

Will cover :

- One left bank enclosure to permit of constructing the lock;

This enclosure will be constitued by concrete walls according to the tide and will be incorporated in the final structure, crest level +14.00 S.C.

- One right bank enclosure supported on the Chalibert rock to permit of constructing the movable dam.

Enclosure consisting of flat web sheet-piling gabions filled with sand.

Gabion diameter 16 to $19 \mathrm{~m}$. Cirest level +14.00 S.C.

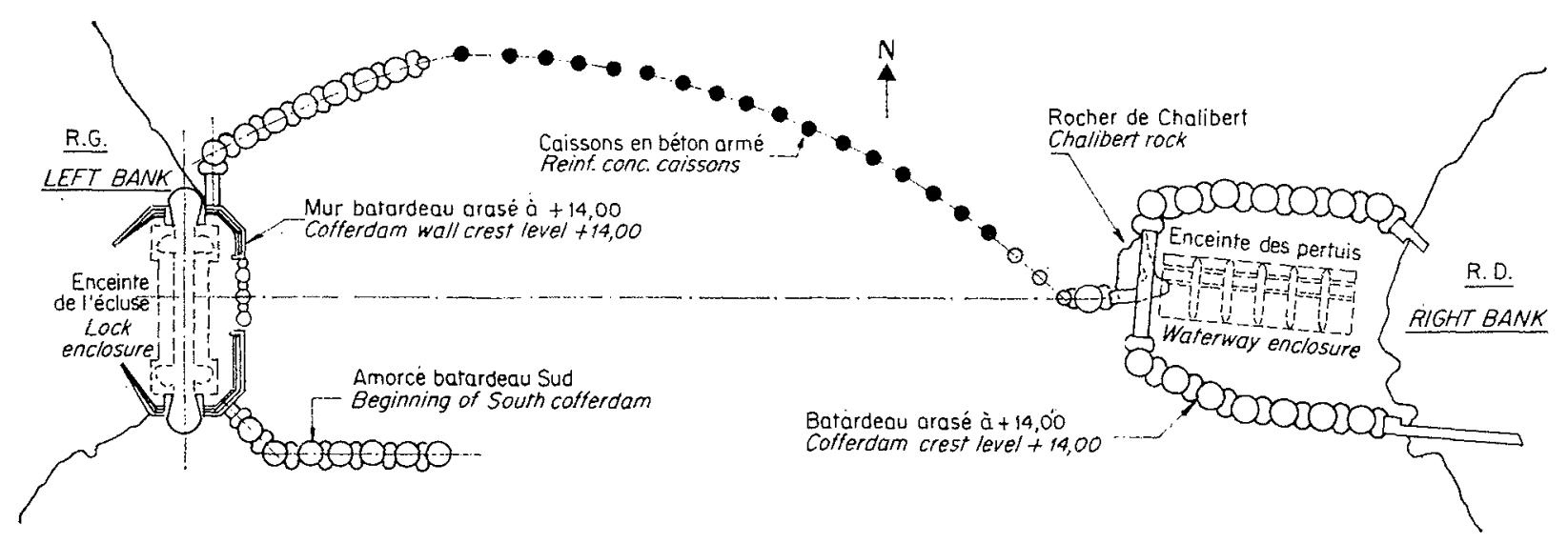

Durant cette première phase on jettera les amorces d'une grande enceinte centrale comportant deux batardeaux : Nord et Sud :

- en construisant à l'avancement des gabions de palplanches à âme plate, remplis de sable;
During this first stage, the implantation of a large central enclosure with two coffer-dams, North and South, will be begun:

- By constructing flat web sheet-piling gabions filled with sand, section by section; 
- en échouant à l'emplacement du batardeau Nord, des caissons en béton armé, sur des fonds préparés à l'avance au moyen d'un caisson à air comprimé permettant le travail sous l'eau. Ces caisses seront remplies de sable.

\section{Deuxième phase}

On terminera la grande enceinte qui permettra la construction de l'usine et de la digue morte.
- By stranding reinforced concrete caissons on the site of the North coffer-dam, on foundations prepared in advance by means of a compressed air caisson enabling work to be carried on under the water. These caissons will be filled with sand.

\section{2nd stage}

The large enclosure will be terminated, thus permitting construction of the power station and the fixed dike.

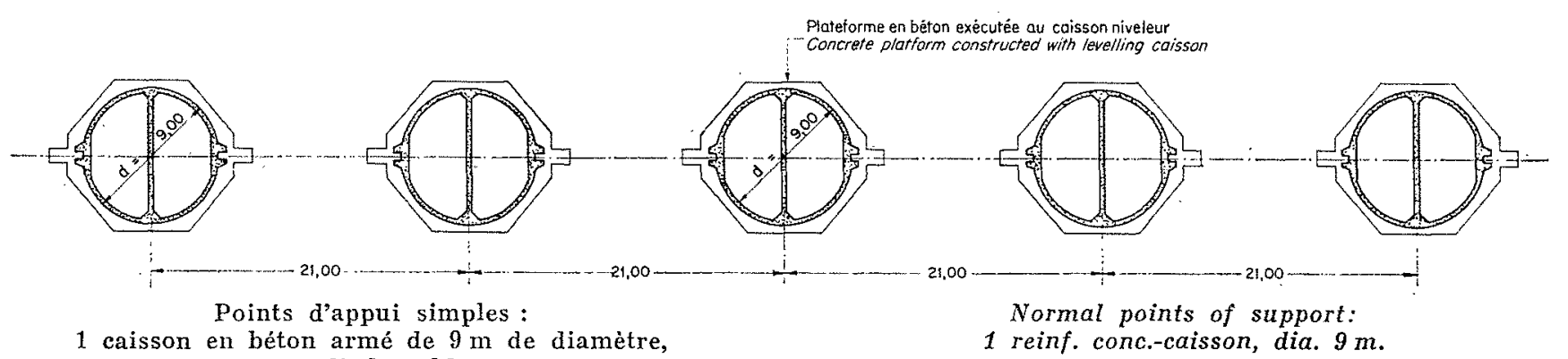
rempli de sable.

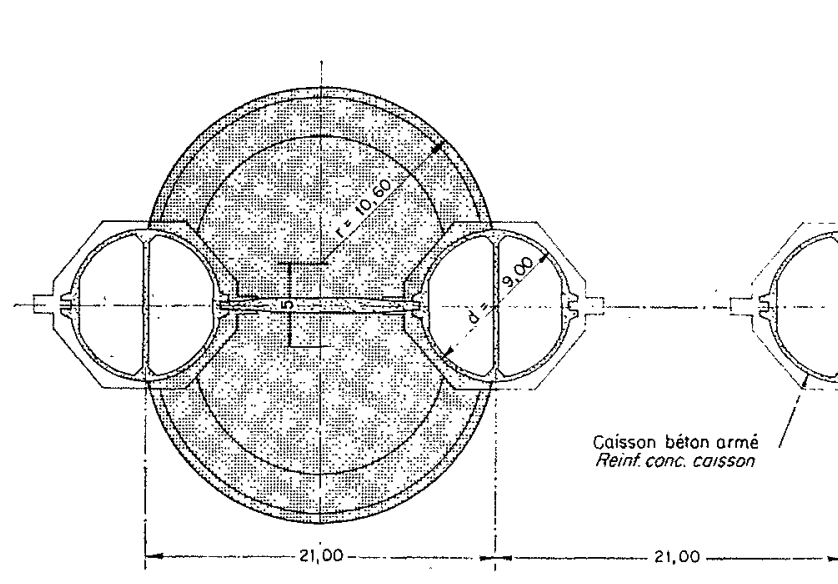

Points d'appui renforcés :

2 caissons et 1 cellule de palplanches

2 caissons et 1 cellule de p
remplis de sable.
1 reinf. conc.-caisson, dia. $9 \mathrm{~m}$.

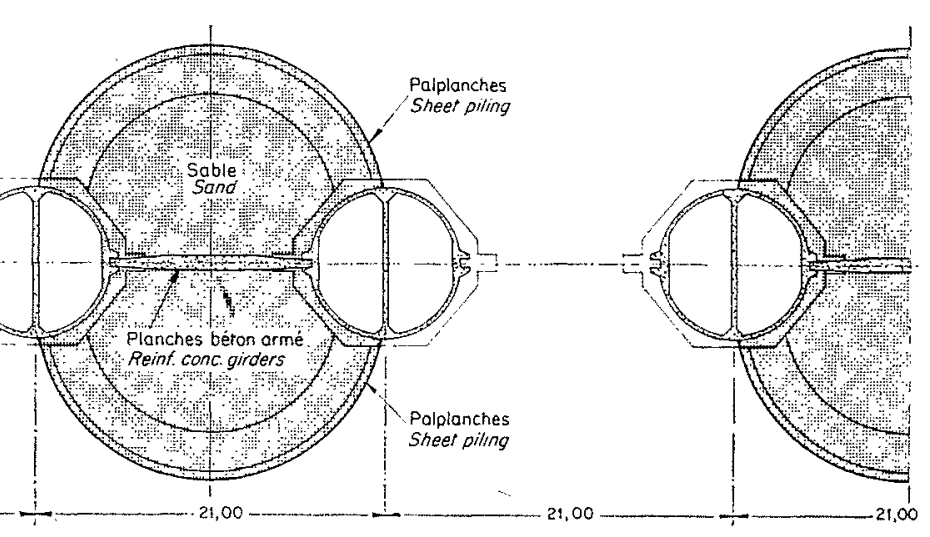

Reinforced points of support:

2 caissons and 1 sheet-piling cell filled with sand.

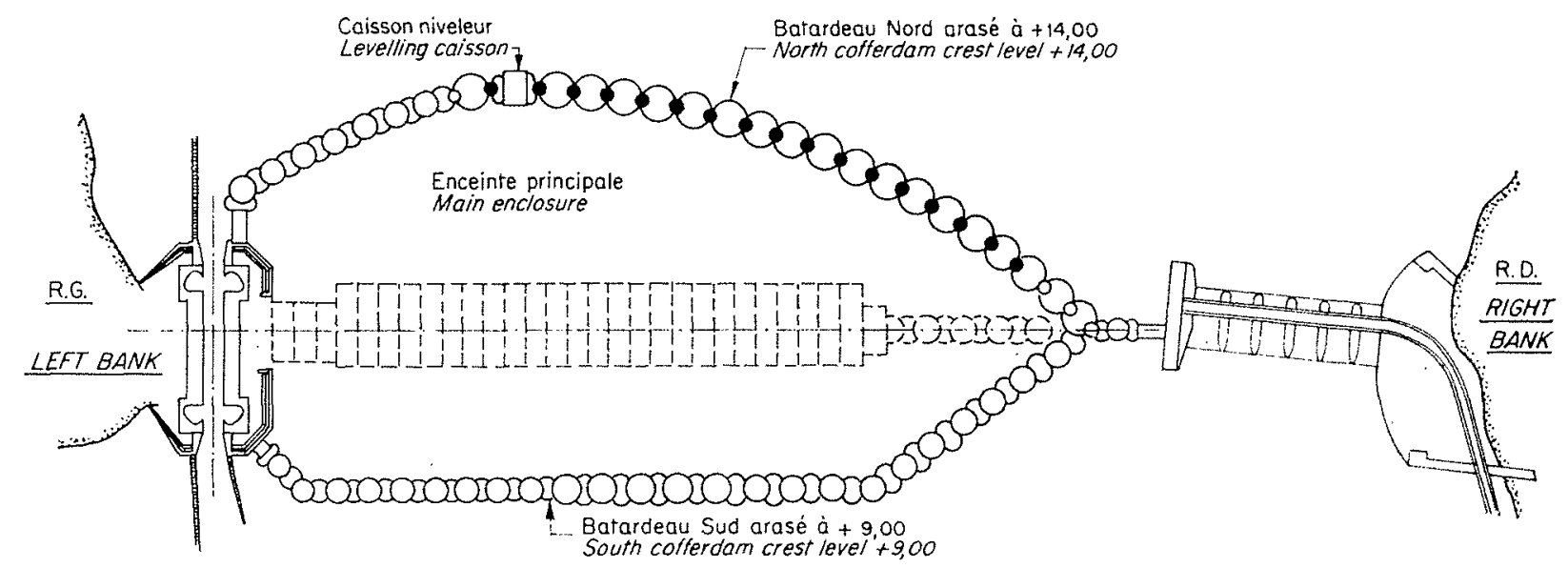


a) L'écluse et les pertuis de vannage ayant été mis en service, on réalisera la «coupure»de la Rance en fermant progressivement les intervalles entre caissons du batardeau Nord dont la cote d'arase est à +14.00 C.M.

Les intervalles seront fermés à raison de 1 sur 2 afin de créer des points d'appui beaucoup plus stables que ne l'étaient les seuls caissons; car au fur et à mesure que la brèche offerte au passage des marées se rétrécit, les dénivellations de part et d'autre du batardeau augmentent.

Pour faciliter la construction des cellules de palplanches entre deux caissons, l'intervalle sera bouché par des poutrelles provisoires afin de couper les courants. Des rainures sont prévues à cet effet dans les caissons.

b) La coupure étant réalisée, les vannes seront fermées et le plan d'eau dans l'estuaire sera maintenu à la cote $+8,50$ C.M., cote suffisante pour permettre la navigation en Rance jusqu'à l'écluse du Chatellier. a) The lock and the waterway gates having been put into service, the Rance will be cut off by progressive closure of the spaces between the caissons of the North coffer-dam the crest level of which is $+14 \mathrm{~S}$. C.

One out of every two of these spaces will be closed so as to give much more stable supports than the caissons alone, because as the breach left for the passage of the tide becomes narrower, the changes in level on both sides of the cofferdam increase.

To facilitate construction of the sheet-piling cells between two caissons, the space will be filled in with temporary girders so as to cut off the currents. Grooves are made in the caissons for this purpose.

b) The currents having been cut off, the sluices will be closed and the water level in the estuary will be maintained at 8,50 S.C. which is sufficient to permit navigation on the Rance as far as the Le Chatellier lock.

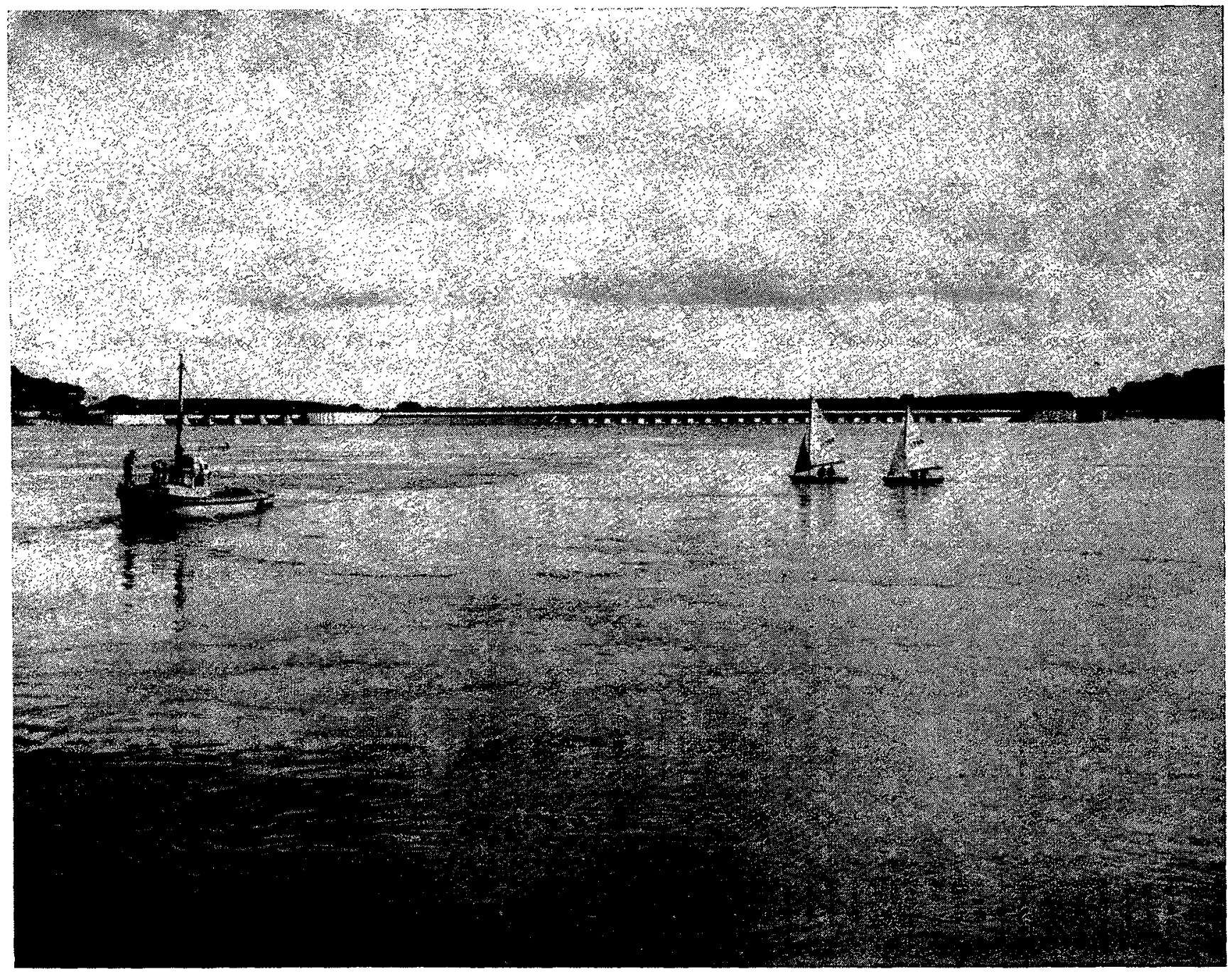


On achèvera le batardeau Sud en eau morte. Celui-ci constitué de gabions de palplanches, sera arasé à la cote +9.00 C.M.

Ce processus d'exécution résulte d'essais faits sur un modèle réduit de la Rance au $1 / 150^{\circ}$ construit sur le terre-plein du Naye, en bordure du port de Saint-Malo-Saint-Servan.

\section{Matériaux mis en œuvre}

OUvRages provisoires (batardeaux):

Bétons. ................. $40000 \mathrm{~m}^{3}$

Palplanches:

Surface de rideaux.......... $90000 \mathrm{~m}^{2}$

Poids correspondant......... $13000 \mathrm{t}$

Sable de remplissage (gabions et caissons en béton armé) ...... $460000 \mathrm{~m}^{3}$

OUVRAGES DEFINITIFS :

Terrassements. ............. $400000 \mathrm{~m}^{3}$

Bétons. . .............. $260000 \mathrm{~m}^{3}$

Aciers. . . .............. $10000 \mathrm{t}$

\section{Puissance et production}

Puissance installée........... 240 MW

Production nette............. 544 GWh se décomposant ainsi :

dans le sens bassin-mer.... 537

dans le sens mer-bassin.... 71,5

Total. .......... 608,5

Energie consommée par le pompage. . ....... - 64,5

Production nette........ 544

\section{Programme}

Début des travaux préparatoires. . . ....... Juillet 1960

Début des travaux défini-

tifs. ........... Ianvier 1961

Durée totale des travaux 6 ans environ

Mise en service des premiers groupes..... dès $\operatorname{la} 5^{e}$ année
The Southern coffer-dam will be finished in still water. Formed of sheet-piling gabions, it will be levelled off at +9.00 .S.C.

This method has been adopted as a result of experiments on a small scale model (1/150) of the Rance built on the Terre-plein du Naye, alongside the Saint-Malo-Saint-Servan port.

\section{Materials used}

Temporary structures (coffer-dams):

Concrete. . . ............. $40000 \mathrm{~m}^{3}$

Sheet piling:

Curtain faces............ $90000 \mathrm{~m}^{2}$

Corresponding weight........ $13000 \mathrm{t}$

Filling sand (Gabions and renforced concrete caissons)......... $460000 \mathrm{~m}^{3}$

Final structures :

Earthworks. .............. $400000 \mathrm{~m}^{3}$

Concrete. . . .............. $260000 \mathrm{~m}^{3}$

Structural steel............ $10000 \mathrm{t}$

\section{Capacity and production}

Installed power............. 240 MW

Net output................ 544 GWh Made up as follows :

basin-to-sea output....... 537

sea-to-bassin output...... 71,5

Total. . . ........ 608,5

Power absorbed by pump-

ing. . . . . . . . . .

Net output. . . . . . . . . . 544

\section{Schedule}

Beginning of preparatory work. . . . ....... July 1960

Beginning of work on final structures....... January 1961

Total duration of works approximat. 6 years Commissioning of first sets.......... as from the 5 th year 